\title{
Soil carbon dynamics and climate change: current agro-environmental perspectives and future dimensions
}

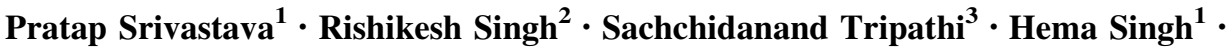 \\ Akhilesh Singh Raghubanshi ${ }^{2}$ \\ ${ }^{1}$ Ecosystems Analysis Laboratory, Department of Botany, Institute of Science, Banaras Hindu University, Varanasi, Uttar Pradesh 221005, India \\ 2 Institute of Environment and Sustainable Development (IESD), Banaras Hindu University, Varanasi, Uttar Pradesh 221005, India \\ ${ }^{3}$ Department of Botany, Deen Dayal Upadhyaya College, University of Delhi, New Delhi 110015, India
}

Received: 2 February 2016/Revised: 29 April 2016/Accepted: 5 May 2016/Published online: 11 May 2016

(C) Joint Center on Global Change and Earth System Science of the University of Maryland and Beijing Normal University and Springer-Verlag Berlin Heidelberg 2016

\begin{abstract}
The management of soil organic carbon (SOC) has now been identified as the most imperative dimension for managing the global climate change as well as soil fertility. In this respect, various agro-ecological approaches such as organic and integrated nutrient management system have been proposed worldwide, though accepted with limited enthusiasm. The understanding of the different soil $\mathrm{C}$ pools and processes are of vital importance before the implementation of these agro-ecological management practices, as it determines the success of SOC management. In the present study, we tried to encompass various SOC pools and processes governing the SOC dynamics in the agro-ecosystems. In this paper, dry tropical ecosystems having a unique ecological behaviour (such as strong nutrient conservation mechanisms and potential $\mathrm{C}$ sink nature) have been discussed especially due to its potential role in global climate change and mitigation, and linked soil fertility. It is proposed that a multi-factorial experimentation involving quantitative and qualitative change in soil available N, microbial and aggregate attributes, which has been recently found to be of crucial significance, is required for the proper mechanistic understanding of SOC dynamics. It may also help in the identification of some
\end{abstract}

Pratap Srivastava

prataps103@gmail.com

$\bowtie$ Akhilesh Singh Raghubanshi

asr.iesd.bhu@gmail.com integrative functional indicators, which can be used to achieve a balanced SOC dynamics via suitable agromanagement.

Keywords Carbon accumulation - Dry tropical ecosystems · Organic systems $\cdot$ Soil $\mathrm{CO}_{2}$ efflux

\section{Introduction}

Human development since industrial revolution has dramatically increased the atmospheric greenhouse gases (GHGs) primarily due to fossil-fuel burning, and land use change and management (USEPA 2014). The concentration of atmospheric $\mathrm{CO}_{2}$ has increased from 280.0 to 398.6 ppm between 1750 and 2014 and is increasing currently at a rate of $2.11 \mathrm{ppm}$ per year $\left(\mathrm{CO}_{2}\right.$ now.org; IPCC 2014). This anthropogenic increase in atmospheric $\mathrm{CO}_{2}$ concentration led to a change in global climate which has been identified as one of the most important scientific and political challenges of the twenty-first century in addition to the closely associated problem of sustainable food production (Abhilash et al. 2016; Saraswat and Kumar 2016; Srivastava et al. 2016a) (Fig. 1). Moreover, soil carbon management is supposed as a most exacerbating area for managing the soil fertility and productivity on the one hand and soil $\mathrm{C}$ sequestration to mitigate the change in climate on the another hand (Lal 2006). It indicates the interrelated nature of various problems humans are facing at present (Chen 2016). Therefore, scientific understanding of pools of soil $\mathrm{C}$ and its efflux from soil ecosystem in relation to agro-management practices is essential for managing the global climate change and soil fertility (Lal 2010). 

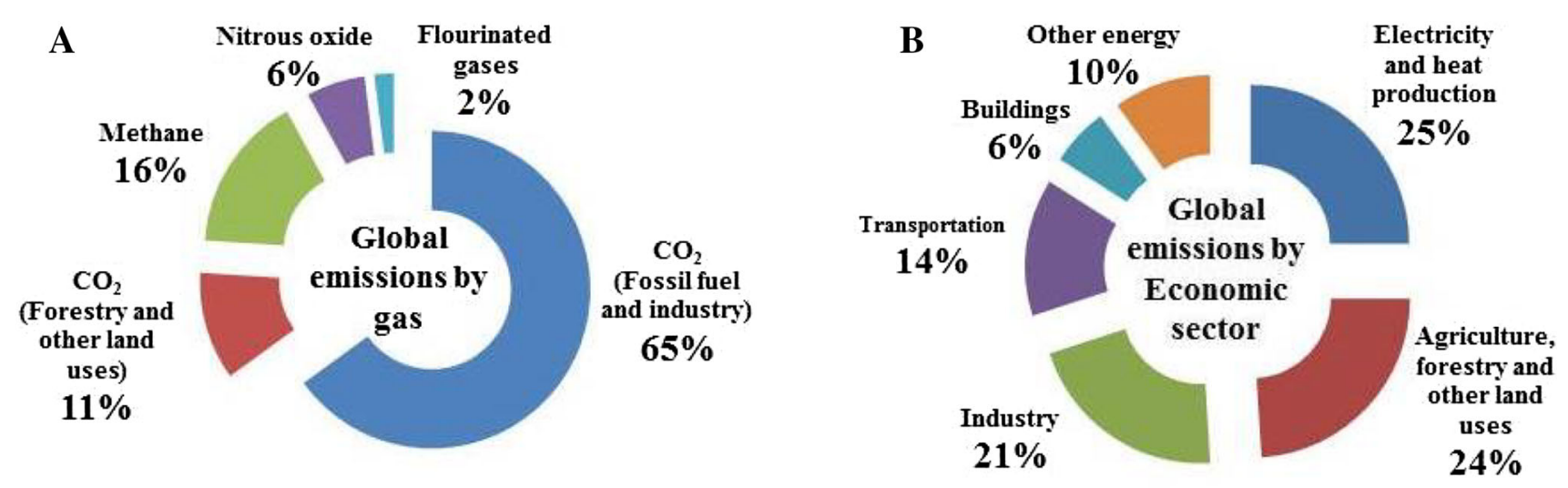

Fig. 1 Major greenhouse gases (a) and their economic sector-wise (b) distribution (adapted and redrawn from IPCC 2014; USEPA 2014)

\section{Carbon dioxide $\left(\mathrm{CO}_{2}\right)$ as a major greenhouse gas}

The $\mathrm{CO}_{2}$ is a major greenhouse gas $(\mathrm{GHG})$ because of its atmospheric concentration (about $398 \mathrm{ppm}$ ) and strongest radiative forcing among all the known GHGs (Fig. 1), despite having relatively lower warming potential (Forster et al. 2007). It, along with atmospheric water vapours, contributes majorly to the greenhouse effect on the earth. Though other GHGs such as methane $\left(\mathrm{CH}_{4}\right)$, nitrous dioxide $\left(\mathrm{NO}_{\mathrm{X}}\right)$ and chlorofluorocarbons (CFCs) are present at lower concentrations (about 2-6 orders of magnitude) than $\mathrm{CO}_{2}$ in the atmosphere, their per molecule absorption of infrared (IR) radiation is many fold higher than $\mathrm{CO}_{2}$. It is now known (Fig. 1) that the major contributors of the enhanced atmospheric GHGs are fossil-fuel combustion, land use changes and increased use of synthetic fertilizers in the agriculture. The deterioration of soil quality following land use change and agro-management practices has drawn global attention towards the soil ecosystem in general and soil organic carbon (SOC) dynamics in particular (FAO 2001; Srivastava et al. 2016a). It is believed that the increased atmospheric $\mathrm{CO}_{2}$, in which land use change and management adds considerably in the form of soil $\mathrm{CO}_{2}$ efflux, can be sequestered back as SOC through appropriate agro-management practices. It may help to mitigate the change in global carbon cycle and climate (Aswathanarayana 2012).

\section{Soil and atmospheric $\mathrm{CO}_{2}$ : source-sink relationships}

Soil, which holds around $1500 \mathrm{Pg} \mathrm{C}$, is now being considered as a major sink of the atmospheric $\mathrm{CO}_{2}$ (Post et al. 1982). It constitutes more than the combined $\mathrm{C}$ in the vegetation and the atmosphere (Batjes and Sombroek
1997). Tropical soil shares $32 \%$ of this SOC stock (Eswaran et al. 1993). The various pools and fluxes of $\mathrm{C}$ on the Earth are depicted in Fig. 2. SOC plays a major regulatory role in biogeochemical cycles and biosphere functioning due to its complex interaction with soil physical, chemical and biological factors and thereby its effect on the soil multi-functionality. SOC plays a central role in defining the soil quality and agro-ecosystem productivity (Lal 2003). It is identified that an increase in SOC may help in alleviating the soil degradation and, thus, ensure sustainable food production for the growing world population (Swift 2001). Therefore, there has been an additional interest in the role of SOC as a potential sink for atmospheric $\mathrm{CO}_{2}$ (Post and Kwon 2000).

Land use change (LUC), especially forest to agriculture conversion, has been identified as a major source of historical loss of SOC, primarily in the form of soil $\mathrm{CO}_{2}$ efflux (Lal 2004; Poeplau and Don 2013). It strongly influences the balance of SOC dynamics which affects the soil $\mathrm{CO}_{2}$ efflux and subsequent $C$ sequestration (Lal 2003). Further, various agro-management practices differentially affect the SOC dynamics (Srivastava et al. 2016a). These management-induced changes in the SOC have been already studied well in agricultural systems in the context of conservation tillage, cropping, organic and synthetic fertilization, and residue incorporation (Lugato et al. 2010; Srivastava et al. 2016a). The intensive crop production practices to increase the crop productivity (i.e. conventional agriculture), which involves agro-chemicals, improved irrigation, high mechanization and high yielding seed varieties, enhance the soil $\mathrm{C}$ mineralization, but induce severe environmental problems (Pimentel et al. 1995). Consequently, it depletes SOC with the time because of continuous harvest and negligible organic input. Therefore, it is essential to understand various pools and processes related with SOC before devising the management policies. 


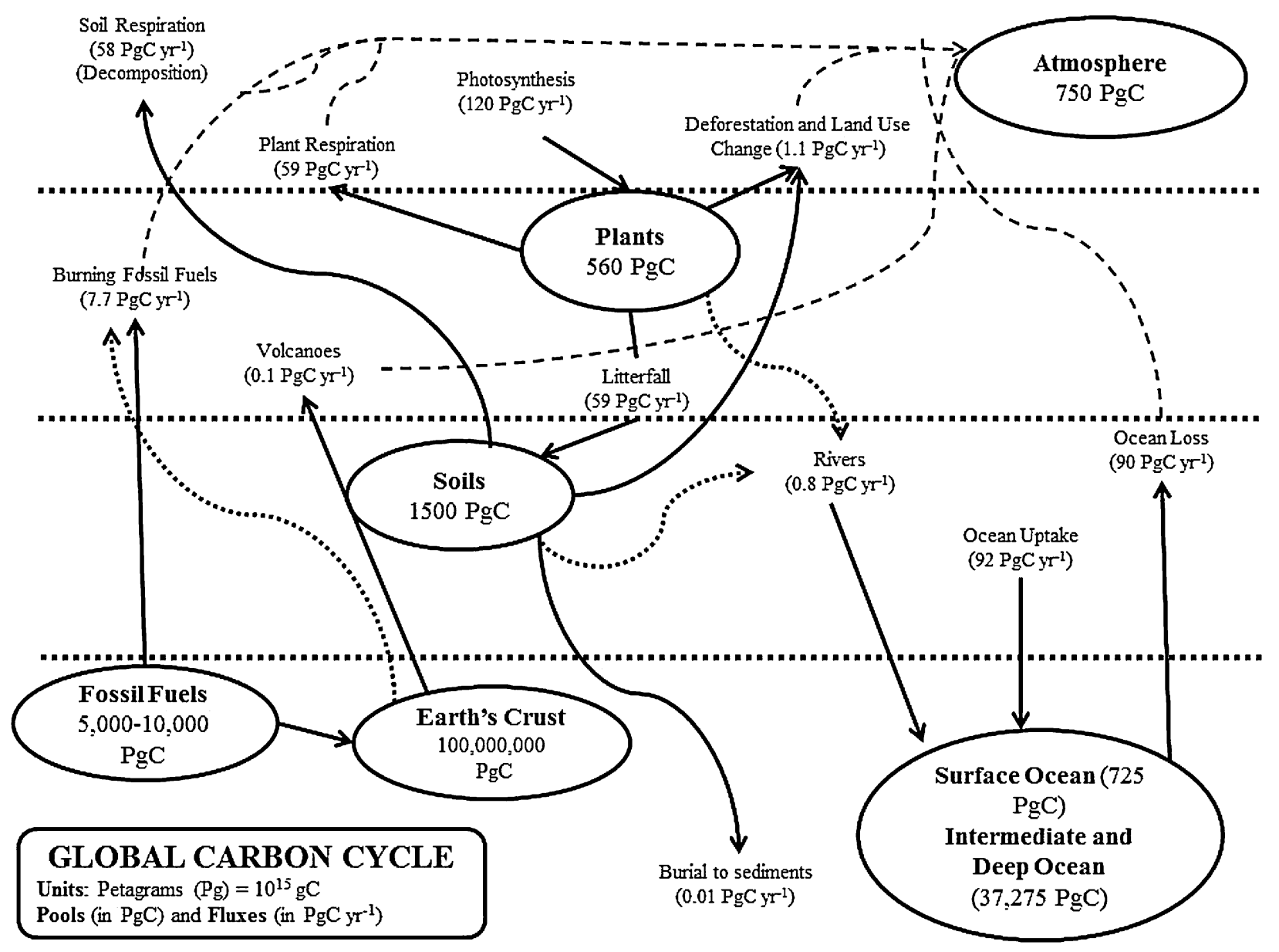

Fig. 2 Global carbon cycle depicting various pools and fluxes of C (adapted and redrawn from Houghton 2007)

\subsection{Soil carbon dynamics}

Soil C dynamics comprise the study of the soil C pools, the rate of its exchange among them (turnover) and the associated regulatory variables (Trumbore 2009). Therefore, it encompasses the kinetics as well as the governing variables, which defines the temporal change in SOC pools among its various compartments. SOC dynamics generally shows a nonlinearity, and several years are required to reach a new equilibrium (Luo et al. 2004). Therefore, the short-term assessments misrepresent the SOC dynamics. However, the long-term datasets to derive the rate of change across the various SOC pools to better understand the SOC dynamics are often scarce (Vaccari et al. 2012).

\subsubsection{Soil carbon pools}

The depletion of the SOC pool leads to a downfall in the soil quality and productivity (Lal 2001). SOC consists of several pools, namely active, slow and passive, with differential turnover rate ranging from months to over several hundred to thousands years (Silveira et al. 2008).

(1) Active SOC pool, also called labile form of $\mathrm{C}$, is primarily made up of fresh plant and animal residues that breakdown in a very short time, from a few weeks to a few years (Fig. 3). This kind of organic matter is associated with a lot of biological activity.

(2) Passive SOC pool, also known as humus or nonlabile form of $\mathrm{C}$, is not biologically active, and thus it provides very little food for soil organisms. It may take hundreds or even thousands of years to fully decompose. It is a dark, complex mixture of significantly transformed organic substances which also contains substances synthesized by the soil organisms. Usually, humus represents the majority of soil organic matter (SOM), and it is relatively stable over time.

(3) Slow SOC pool is somewhere in between active and passive SOM. It consists primarily of detritus (i.e. 
Fig. 3 Characteristics of different soil organic $\mathrm{C}$ pools and soil $\mathrm{CO}_{2}$ efflux (adapted and redrawn from Trumbore 1997)

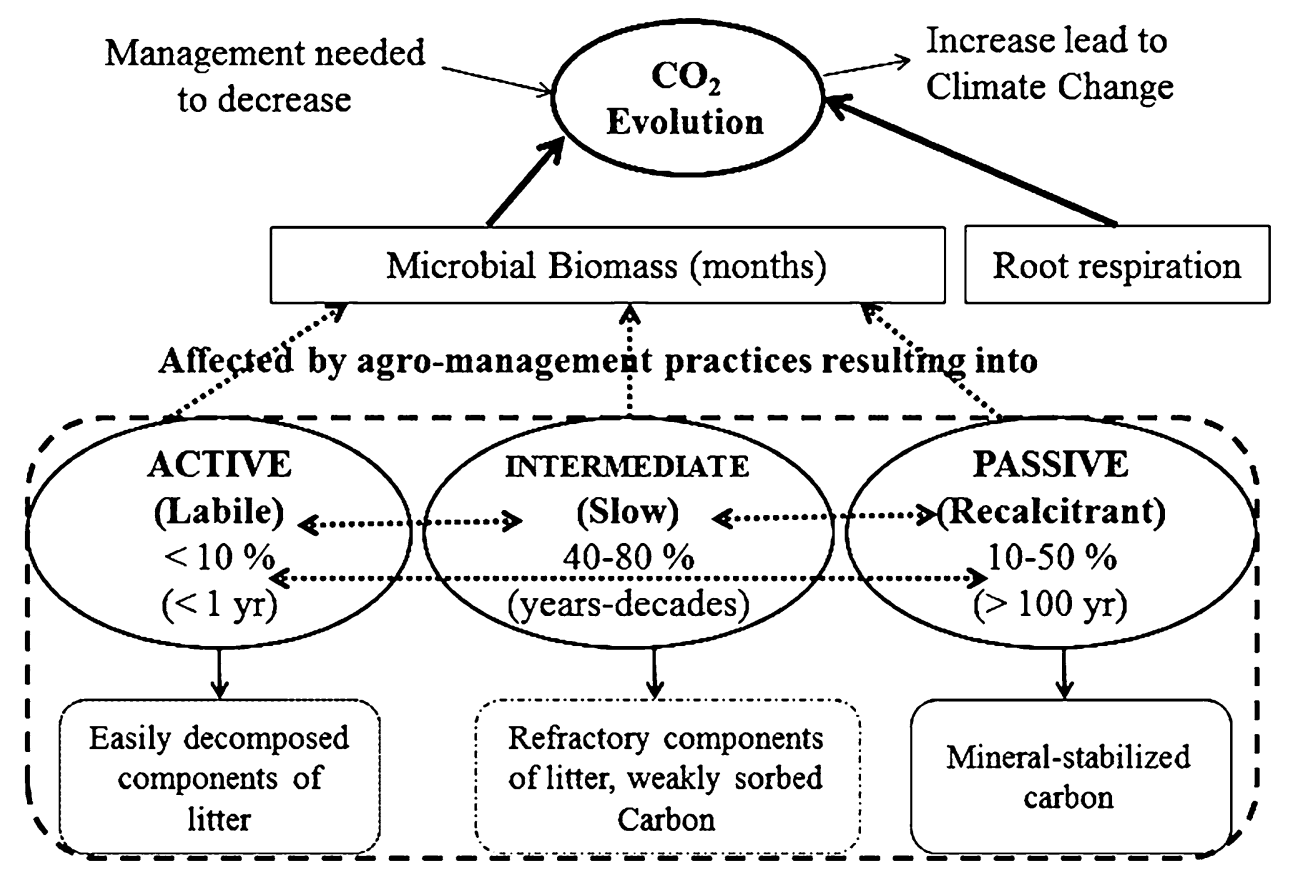

partially broken down cells and tissues), which decomposes gradually. Slow SOM is somewhat resistant to decay than active pools and may take a few years to a few decades to breakdown completely.

In general, the turnover rate of labile $\mathrm{C}$ pool ranges from several weeks to months or years, whereas recalcitrant, non-labile pools have a turnover rate of centuries to millennia (Paul et al. 2001; Singh et al. 2015). Labile C pool comprises easily oxidizable forms of SOC such as microbial biomass carbon (MBC), water-soluble carbon (WSC), particulate organic carbon (POC), which responds more rapidly to the agro-management practices (Blair et al. 1995; Purakayastha et al. 2008). The decomposition of labile $\mathrm{C}$ by soil microorganisms helps to stabilize the soil aggregates, releases nutrients by mineralization and provides food for soil microbial activity. Thus, it can serve as the sensitive indicator of soil quality (Blair et al. 1995; Purakayastha et al. 2008). Additionally, it plays an important role in improving soil quality and thus can minimize the negative environmental impacts. The amount of these active fractions and their proportion to total SOM are the good indicators of soil health. Therefore, the identification of highly sensitive SOC fractions may help to elucidate changes and trajectories in the SOC pool at early stages of changes in land use and management (Yang et al. 2009). Active SOC pool plays a very different role than passive does. As labile (active) and non-labile (stable) SOC play differential roles in SOM dynamics and nutrient cycling, the pool size and turnover time of these two fractions in bulk soil and in aggregate size fractions may be important to assess and evaluate the soil management practices for the monitoring of SOC (Lutzow et al. 2007; Srivastava et al. 2016b).

Dissolved organic C constitutes an important labile SOM fraction (Zsolnay 1996), which acts as a primary source of energy and nutrients for the soil microorganisms. Thus, its turnover is strongly linked to the soil microbial activity (Chantigny 2003) and soil nutrient availability. It affects the important soil functions, such as soil physical stability and $\mathrm{C}$ sequestration in multiple ways (Zsolnay 1996; Chantigny 2003). Therefore, understanding of temporal dynamics of quantity and quality of DOC and similar labile $\mathrm{C}$ fractions would help to better manage soil $\mathrm{C}$ sequestration in agroecosystems.

\subsubsection{Soil carbon processes}

Decomposition, a biogeochemical transformation process, releases major SOC portions as soil $\mathrm{CO}_{2}$ efflux (Post and Kwon 2000). It defines the characteristics, storage, turnover and transfer of $\mathrm{C}$ among various aggregate and particle size fractions, and thus indirectly determines SOC sequestration and soil $\mathrm{CO}_{2}$ efflux (Adams et al. 2011). Being a microbial mediated process, it is sensitive to land use and management. Soil microbes typically are C-limited (Smith and Paul 1990) and act as a source of plant nutrient in the dry tropical ecosystems (Singh et al. 1989). Changes in the SOC are highly related to the soil microorganisms due to their primary role in nutrient cycling and SOC turnover (Smith and Paul 1990; Ryan et al. 2009). During the microbial decomposition, organic residues are 
converted to humic substances via a SOC sequestration process termed as humification (Guggenberger 2005; Stockmann et al. 2013). In humification, the aromatic and paraffinic $\mathrm{C}$ increases, while the O-alkyl C decreases (Inbar et al. 1990).

Further, SOC closely relates to the soil aggregate formation and stability (Tisdall and Oades 1982). It has been recently identified that not only the chemical recalcitrance but biophysical processes (i.e. aggregate formation and dynamics) also act crucially in the turnover and sequestration of SOC (Schmidt et al. 2011). Thus, SOC turnover is governed by the accessibility of organic substrates to decomposers (Dungait et al. 2012), as well as by the chemical nature of the stored material (Conant et al. 2011). Soil aggregate occludes the SOC physico-chemically from microbial decomposition. Its dynamics (size distribution and $\mathrm{C}$ characteristics) is found to be dependent on management (Singh and Singh 1995). It determines the efficiency of $\mathrm{C}$ protection from decomposition due to its strong impact on the extent and manner of soil aggregate development. The soil management practices in agriculture have shown a significant impact on soil aggregate stability and dynamics (Bhattacharya et al. 2010), which is now being identified as a major player in climate change and loss of soil fertility.

\section{Soil carbon management}

The content and distribution of SOC across depth, compartments and aggregate size fractions are reportedly more sensitive to the land use changes (Leifeld and Kögel-Knabner 2005). It is evident by a decrease in the SOC pools and associated soil quality following the anthropogenic conversion of native forest to agriculture (Brown and Lugo 1990). Therefore, the restoration of SOC via soil management has the potential to sequester significant amount of $\mathrm{C}$ from the atmosphere into the soil (Lal 2004). Agromanagement practices determines the global $\mathrm{C}$ cycle and SOC dynamics affecting soil aggregates as well as microbial communities and their activities (Six et al. 2004).

Organic amendments have been proposed as a means to increase the soil C storage (Powlson et al. 2012). It may occur directly from the $\mathrm{C}$ inputs in the form of organic amendments and indirectly due to increased plant production due to amendment (Whalen and Chang 2002; Ryals and Silver 2013). It has also been found related to the enhanced soil water-holding capacity, decreased bulk density and improved soil fertility (Mader et al. 2002; Lynch et al. 2005). Moreover, organic amendments may also increase the organic nitrogen $(\mathrm{SON})$ in soils, which could act as a slow release fertilizer and enhance the net primary productivity of the ecosystem (Ryals and Silver 2013). Manure application increases the SOC concentration, aggregate stability and soil biological activities, which altogether relates to improved soil structure (Jarecki and Lal 2003). Long-term studies have shown an increase in the soil microbial biomass under fertilization (Yan et al. 2007). Most studies report that the application of organic manure with/without inorganic fertilizers can manipulate the soil microorganisms to improve the soil health and fertility (Chaparro et al. 2012). It influences the soil microbial biomass, activity and community (Singh and Singh 1993; Jimenez et al. 2002; Goyal et al. 1999). Soil microbial biomass and activity has been found higher in the organic than conventional management system (Tu et al. 2006). Moreover, integrated use of fertilizers has been reported to accumulate higher SOC and its fractions as compared to sole chemical fertilization in some studies (Lal 2003; Purakayastha et al. 2008). However, several studies under integrated amendment have shown either little or no effects on the SOC content (Purakayastha et al. 2008). These contrasting effects of the management practices can be attributed to the climatic conditions that influence the plant and soil processes, which determine SOC dynamics (Ogle et al. 2005).

Agricultural management defines the SOC dynamics affecting soil processes (Ogle et al. 2005). In agroecosystems, enhanced nutrient availability through chemical fertilization enhances the yield, but negatively affects the SOC with the time. More specifically, soil $\mathrm{N}$ is a crucial driver of SOM dynamics in the agroecosystems. For example, the differential dynamics of soil $\mathrm{NH}_{4}{ }^{+}-\mathrm{N}$ and $\mathrm{NO}_{3}{ }^{-}-\mathrm{N}$ (which may shift the soil ammonium-N to nitrate-N ratio; ANR) may have an important ecological significance as it may affect the important ecosystem properties (Bijlsma et al. 2000; Srivastava et al. 2015, 2016b). Differential shift in the soil $\mathrm{NH}_{4}{ }^{+}-\mathrm{N}$ and $\mathrm{NO}_{3}{ }^{-}-\mathrm{N}$ concentration may have important ecosystem consequences in the changing environment in different ways (Cruz et al. 2003; Srivastava et al. 2015, 2016b). The differential availability of soil $\mathrm{NH}_{4}{ }^{+}-\mathrm{N}$ and $\mathrm{NO}_{3}{ }^{-}-\mathrm{N}$ may have implication on SOC turnover because of their contrasting effects (Currey et al. 2010; Srivastava et al. 2015). Literature findings (Min et al. 2011; Srivastava et al. 2015, $2016 b$ ) suggest that the forms of inorganic $\mathrm{N}$ (i.e. soil $\mathrm{NH}_{4}{ }^{+}-\mathrm{N}$ or $\mathrm{NO}_{3}{ }^{-}-\mathrm{N}$ ) could differentially influence the rate of SOC cycling and thus $\mathrm{C}$ mineralization via changes in the soil chemical and biological attributes. Jha et al. (1996) reported that soil moisture content affects the soil nitrification more than ammonification, importantly at low water tension, through dehydration and substrate limitation. A significant relationship between the soil $\mathrm{CO}_{2}$ efflux and gross $\mathrm{N}$-mineralization is well reported in the literature (Flavel and Murphy 2006). 
Depending on the management, soil microbial behaviour may differentially define the qualitative and quantitative change in the availability of $\mathrm{C}$ substrate and nutrient, particularly of the available N (Srivastava et al. 2016b). These changes may further affect the downward processes via cascade effect which may lead to differential response in the distribution, composition and function of soil microbial community as well as $\mathrm{C}$ characteristics across aggregate size fractions (Srivastava et al. 2016b). It is supposed that these changes altogether would lead to a differential aggregate dynamics, which determines the nature of soil $\mathrm{C}$ dynamics and degree of $\mathrm{C}$ sequestration, depending on the applied management system.

Limited studies are available from the tropics which deal with the qualitative and quantitative effects of LUC on SOC across aggregate size fractions. The temporal effect of sustainable management practices (such as organic and integrated management) on the soil aggregate characteristics is limited (Nicolás et al. 2014), particularly in the dry tropical ecosystem (Singh et al. 1989). This ecosystem is potentially unique due to its significant coverage (41\%) and human population as well as potential C sink nature. In these ecosystems, conversion of forest to chemical fertilizer-based agriculture has already led to a significant decline in SOC (Srivastava et al. 2015). These ecosystems are in the core of discussion related to global climate change due to their potential as an important $\mathrm{C}$ sink nature (Lal 2004). If managed properly, these ecosystems may help in the reduction of atmospheric $\mathrm{CO}_{2}$ with the added benefit of improvement in the soil quality. Therefore, temporal changes in soil $\mathrm{C}$ dynamics and sequestration under long-term organic amendments, either individually or in an integrated manner, are urgently required in the dry tropical ecosystems. These studies would help in the better mechanistic understanding for soil $\mathrm{C}$ dynamics for its improved management and in understanding the response of these ecosystems to the climate change.

\section{Conclusion and future research needs}

Carbon sequestration in soils as SOC through agro-management practices has been widely considered as a promising option for the mitigation of global climate change simultaneous to soil infertility. Therefore, a thorough understanding of SOC dynamics and its relationship with the management practices is highly required. It would help to fine tune the agro-management practices in a sitespecific manner to potentially sequester SOC to reap sustainable benefits from the soil ecosystem. Long-term studies on the interaction between the soil aggregate dynamics, soil $\mathrm{N}$ availability and microbial attributes in relation to SOC dynamics under sustainable nutrient management practices have been scarcely done, quantitatively as well as qualitatively. In a recent study, SOC dynamics has been found to be dependent on both qualitative and quantitative characteristics of these attributes. It was found related to the relative availability of soil inorganic-N pools, which is due to its relationship with soil aggregate physical and chemical stability as well as microbial quantitative and qualitative attributes. Therefore, a multi-factorial experimentation involving the qualitative and quantitative attributes of available soil inorganic- $\mathrm{N}$, microbial and aggregates is needed under various proposed sustainable management practices for the identification of integrative indicator variable and for the mechanistic understanding of SOC dynamics for sustainable SOC management.

Acknowledgments Authors are highly thankful to Prof. J S Singh, Emeritus Professor, Department of Botany, Banaras Hindu University, Varanasi, for his guidance and suggestions. University Grant Commission (UGC) and Council of Scientific and Industrial Research (CSIR) are also acknowledged for providing the research fellowships. The unknown reviewers are highly acknowledged for their suggestions regarding the improvement in the manuscript.

Author contribution A.S.R. and H.S. proposed the theme of the manuscript. P.S. drafted the manuscript in major consultation with A.S.R. and R.S. which was jointly finalized by P.S., R.S., S.T., H.S. and A.S.R.

\section{References}

Abhilash PC, Tripathi V, Edrisi SA, Dubey RK, Bakshi M, Dubey PK, Singh HB, Ebbs SD (2016) Sustainability of crop production from polluted lands. Energy Ecol Environ 1:54-65

Adams M, Crawford J, Field D, Henakaarchchi N, Jenkins M, McBratney A et al (2011) Managing the soil-plant system to mitigate atmospheric $\mathrm{CO}_{2}$. Discussion paper for the Soil Carbon Sequestration Summit, 31 January-2 February 2011. The United States Studies Centre at the University of Sydney

Aswathanarayana U (ed) (2012) Natural resources-technology, economics and policy. CRC Press, Boca Raton

Batjes NH, Sombroek WG (1997) Possibilities for carbon sequestration in tropical and subtropical soils. Glob Change Biol 3:161-173

Bhattacharya R, Prakash V, Kundu S, Srivastava AK, Gupta HS, Mitra S (2010) Long term effects of fertilization on carbon and nitrogen sequestration and associated carbon and nitrogen in the Indian sub-Himalaya. Nutr Cycl Agroecosyst 86:1-16

Bijlsma RJ, Lambers H, Kooijman SALM (2000) A dynamic wholeplant model of integrated metabolism of nitrogen and carbon. 1. Comparative ecological implications of ammonium-nitrate interactions. Plant Soil 220:49-69

Blair GJ, Lefroy RDB, Lise L (1995) Soil carbon fractions based on their degree of oxidation, and the development of a carbon management index for agricultural systems. Aust J Agric Res 46:1459-1466

Brown S, Lugo A (1990) Effect of forest clearing and succession of the carbon and nitrogen content of soils in Puerto Rico and US virgin soils. Plant Soil 124:53-64 
Chantigny MH (2003) Dissolved and water-extractable organic matter in soils: a review on the influence of land use and management practices. Geoderma 113:357-380

Chaparro JM, Sheflin AM, Manter DK, Vivanco JM (2012) Manipulating the soil microbiome to increase soil health and plant fertility. Biol Fert Soils 48:489-499

Chen B (2016) Energy, ecology and environment: a nexus perspective. Energy Ecol Environ 1:1-2

Conant RT, Ogle SM, Paul EA, Paustian K (2011) Measuring and monitoring soil organic carbon stocks in agricultural lands for climate mitigation. Front Ecol Environ 9:169-173

Cruz C, Lips H, Martins-Loução MA (2003) Nitrogen use efficiency by a slow-growing species as affected by $\mathrm{CO}_{2}$ levels, root temperature, $\mathrm{N}$ source and availability. J Plant Physiol 160:1421-1428

Currey PM, Johnson D, Sheppard LJ, Leith ID, Toberman H, Vanderwal R, Artz RR (2010) Turnover of labile and recalcitrant soil carbon differ in response to nitrate and ammonium deposition in an ombrotrophic peatland. Glob Change Biol 16:2307-2321

Dungait JAJ, Hopkins DW, Gregory AS, Whitmore AP (2012) SOM turnover is governed by accessibility not recalcitrance. Glob Change Biol 18:1781-1796

Eswaran H, Vandenberg E, Reich P (1993) Organic carbon in soils of the world. Soil Sci Soc Am J 57:192-194

FAO (2001) Soil carbon sequestration for improved land management. World Soil Resources Reports 96, FAO, Rome

Flavel TC, Murphy DV (2006) Carbon and nitrogen mineralization rates after application of organic amendments to soil. J Environ Qual 35:183-193

Forster P, Ramaswamy V, Artaxo P, Berntsen T, Betts R, Fahey DW et al (2007) Changes in atmospheric constituents and in radiative forcing. In: Climate change (2007). The physical science basis, Chapter 2

Goyal S, Chander K, Mundra MC, Kapoor KK (1999) Influence of inorganic fertilizers and organic amendments on soil organic matter and soil microbial properties under tropical conditions. Biol Fert Soils 29:196-200

Guggenberger G (2005) Humification and mineralization in soils. Microorganisms in soils: roles in genesis and functions. Springer, Berlin Heidelberg, pp 85-106

Houghton RA (2007) Balancing the global carbon budget. Annu Rev Earth Planet Sci 35:313-347

Inbar Y, Chen Y, Hadar Y (1990) Humic substances formed during the composting of organic matter. Soil Sci Soc Am J 54:1316-1323

IPCC (2014) Climate change 2014 synthesis report. Fifth assessment report. http://ar5-syr.ipcc.ch/. Accessed 26 Jan 2016

Jarecki MK, Lal R (2003) Crop management for soil carbon sequestration. Crit Rev Plant Sci 22:471-502

Jha PB, Singh JS, Kashyap AK (1996) Dynamics of viable nitrifier community and nutrient availability in dry tropical forest habitat as affected by cultivation and soil texture. Plant Soil 180:277-285

Jimenez M, Horra AM, Pruzzo L, Palma RM (2002) Soil quality: a new index based on microbiological and biochemical parameters. Biol Fert Soil 35:302-306

Lal R (2001) Soil degradation by erosion. Land Degrad Dev 12:519-539

Lal R (2003) Global potential of soil carbon sequestration to mitigate the greenhouse effect. Crit Rev Plant Sci 22:151-184

Lal R (2004) Soil carbon sequestration to mitigate climate change. Geoderma 123:1-22

Lal R (2006) Enhancing crop yields in the developing countries through restoration of the soil organic carbon pool in agricultural lands. Land Degrad Dev 17:197-209
Lal R (2010) Managing soils and ecosystems for mitigating anthropogenic carbon emissions and advancing global food security. BoiScience 60:708-721

Leifeld J, Kögel-Knabner I (2005) Soil organic matter fractions as early indicators for carbon stock changes under different landuse? Geoderma 124:143-155

Lugato E, Simonetti G, Morari F, Nardi S, Berti A, Giardini L (2010) Distribution of organic and humic carbon in wet-sieved aggregates of different soils under long-term fertilization experiment. Geoderma 157:80-85

Luo Y, Su BO, Currie WS, Dukes JS, Finzi A, Hartwig U et al (2004) Progressive nitrogen limitation of ecosystem responses to rising atmospheric carbon dioxide. Bioscience 54:731-739

Lutzow M, Kogel-Knabner I, Ekschmitt K, Flessa H, Guggenberger G, Matzner E, Marschner B (2007) SOM fractionation methods: relevance to functional pools and to stabilization mechanisms. Soil Biol Biochem 39:2183-2207

Lynch DH, Voroney RP, Warman PR (2005) Soil physical properties and organic matter fractions under forages receiving composts, manure or fertilizer. Compos Sci Util 13:252-261

Mader P, Fliessbach A, Dubois D, Gunst L, Fried P, Niggli U (2002) Soil fertility and biodiversity in organic farming. Science 296:1694-1697

Min K, Kang H, Lee D (2011) Effects of ammonium and nitrate additions on carbon mineralization in wetland soils. Soil Biol Biochem 43:2461-2469

Nicolás C, Kennedy JN, Hernández T, García C, Six J (2014) Soil aggregation in a semiarid soil amended with composted and noncomposted sewage sludge-a field experiment. Geoderma 219:24-31

Ogle SM, Breidt FJ, Paustian K (2005) Agricultural management impacts on soil organic carbon storage under moist and dry climatic conditions of temperate and tropical regions. Biogeochemistry $72: 87-121$

Paul EA, Collins HP, Leavitt SW (2001) Dynamics of resistant soil carbon of Midwestern agricultural soils measured by naturally occurring $14 \mathrm{C}$ abundance. Geoderma 104:239-256

Pimentel D, Harvey C, Resosudarmo P, Sinclair K, Kurz D, McNair M, Crist S, Shpritz L, Fitton L, Saffouri R, Blair R (1995) Environmental and economic costs of soil erosion and conservation benefits. Science 267:1117-1123

Poeplau C, Don A (2013) Sensitivity of soil organic carbon stocks and fractions to different land-use changes across Europe. Geoderma 192:189-201

Post WM, Kwon KC (2000) Soil carbon sequestration and land-use change: processes and potential. Glob Change Biol 6:317-327

Post WM, Emanuel WR, Zinke PJ, Stangenberger AG (1982) Soil carbon pools and world life zones. Nature 298:156-159

Powlson DS, Bhogal A, Chambers BJ, Coleman K, Macdonald AJ, Goulding KWT, Whitmore AP (2012) The potential to increase soil carbon stocks through reduced tillage or organic material additions in England and Wales: a case study. Agric Ecosyst Environ 146:23-33

Purakayastha TJ, Rudrappa L, Singh D, Swarup A, Bhadraray S (2008) Long-term impact of fertilizers on soil organic carbon pools and sequestration rates in maize-wheat-cowpea cropping system. Geoderma 144:370-378

Ryals R, Silver WL (2013) Effects of organic matter amendments on net primary productivity and greenhouse gas emissions in annual grasslands. Ecol Appl 23:46-69

Ryan J, Masri S, Singh M (2009) Seasonal changes in soil organic matter and biomass and labile forms of carbon as influenced by crop rotations. Comm Soil Sci Plant 40:188-199

Saraswat C, Kumar P (2016) Climate justice in lieu of climate change: a sustainable approach to respond to the climate change 
injustice and an awakening of the environmental movement. DOI, Energy Ecol Environ. doi:10.1007/s40974-015-0001-8

Schmidt MWI, Torn MS, Abiven S, Dittmar T, Guggenberger G, Janssens IA, Kleber M, Kögel-Knabner I, Lehmann J, Manning DA (2011) Persistence of soil organic matter as an ecosystem property. Nature 478:49-56

Silveira ML, Comerford NB, Reddy KR, Cooper WT, El-Rifai H (2008) Characterization of soil organic carbon pools by acid hydrolysis. Geoderma 144:405-414

Singh H, Singh KP (1993) Effect of residue placement and chemical fertilizer on soil microbial biomass under tropical dryland cultivation. Biol Fert Soils 16:275-281

Singh S, Singh JS (1995) Microbial biomass associated with waterstable aggregates in forest, savanna and cropland soils of a seasonally dry tropical region, India. Soil Biol Biochem 27:1027-1033

Singh JS, Raghubanshi AS, Singh RS, Srivastava SC (1989) Microbial biomass acts as a source of plant nutrients in dry tropical forests and savannah. Nature 338:499-500

Singh R, Babu JN, Kumar R, Srivastava P, Singh P, Raghubanshi AS (2015) Multifaceted application of crop residue biochar as a tool for sustainable agriculture: an ecological perspective. Ecol Eng 77:324-347

Six J, Bossuyt H, Degryze S, Denef K (2004) A history of research on the link between (micro) aggregates, soil biota, and soil organic matter dynamics. Soil Till Res 79:7-31

Smith JL, Paul EA (1990) The significance of soil microbial biomass estimations. In: Bollag JM, Stotzky G (eds) Soil biochemistry, vol 6. Marcel Dekker, New York, pp 357-396

Srivastava P, Raghubanshi AS, Singh R, Tripathi SN (2015) Soil carbon efflux and sequestration as a function of relative availability of inorganic $\mathrm{N}$ pools in dry tropical agroecosystem. Appl Soil Ecol 96:1-6

Srivastava P, Singh PK, Singh R, Bhadouria R, Singh DK, Singh S, Afreen T, Tripathi SN, Singh P, Singh H, Raghubanshi AS (2016a) Relative availability of inorganic N-pools shifts under land use change: an unexplored variable in soil carbon dynamics. Ecol Ind 64:228-236
Srivastava P, Singh R, Tripathi S, Raghubanshi AS (2016b) An urgent need for sustainable thinking in agriculture - an Indian scenario. Ecol Ind 67:611-622

Stockmann U, Adams MA, Crawford JW, Field DJ, Henakaarchchi N, Jenkins $M$ et al (2013) The knowns, known unknowns and unknowns of sequestration of soil organic carbon. Agric Ecosyst Environ 164:80-99

Swift RS (2001) Sequestration of carbon by soil. Soil Sci 166:858-871

Tisdall JM, Oades JM (1982) Organic matter and water-stable aggregates in soils. J Soil Sci 33:141-163

Trumbore SE (1997) Potential responses of soil organic carbon to global environmental change. Proc Nat Acad Sci 94:8284-8291

Trumbore S (2009) Radiocarbon and soil carbon dynamics. Ann Rev Earth Planet Sci 37:47-66

Tu C, Ristaino JB, Hu S (2006) Soil microbial biomass and activity in organic tomato farming systems: effects of organic inputs and straw mulching. Soil Biol Biochem 38:247-255

USEPA (2014) U.S. National Climate Assessment. http://nca2014. globalchange.gov/. Accessed 26 Jan 2016

Vaccari FP, Lugato E, Gioli B, D'Acqui L, Genesio L, Toscano P et al (2012) Land use change and soil organic carbon dynamics in Mediterranean agro-ecosystems: the case study of Pianosa Island. Geoderma 175:29-36

Whalen JK, Chang C (2002) Macroaggregate characteristics in cultivated soils after 25 years annual manure applications. Soil Sci Soc Am J 66:1637-1647

Yan H, Cao M, Liu J, Tao B (2007) Potential and sustainability for carbon sequestration with improved soil management in agricultural soils of China. Agric Ecosyst Environ 121:325-335

Yang Y, Guo J, Chen G, Yin Y, Gao R, Lin C (2009) Effects of forest conversion on soil labile organic carbon fractions and aggregate stability in subtropical China. Plant Soil 323:153-162

Zsolnay A (1996) Dissolved humus in soil waters. In: Piccolo A (ed) Humic substances in terrestrial ecosystems. Elsevier, Amsterdam, pp 171-223 